\title{
NOTE
}

\section{Rafting of tropical marine organisms on buoyant coralla}

\author{
L. M. DeVantier* \\ Department of Zoology, University of Queensland. St. Lucia, Brisbane, 4072 Queensland, Australia
}

\begin{abstract}
Coral reef species are amongst the most widespread of all organisms, via dispersal of teleplanic larvae in oceanic surface currents and transport of adults on floating rafts. This note describes the rafting of tropical marine organisms on a buoyant skeleton of the reef coral Symphyllia agaricia. When found drifting on the Great Barrier Reef, the corallum was covered in coralline and filamentous algae and supported goose barnacles, decapod crustaceans, pearl and reef oysters, gastropods, foraminiferans and bryozoans. The size structures of the rafted species suggested that the corallum had been floating for several months. Bouyancy was due to gas trapped within the coral's septal chambers. The gas was qualitatively similar to air but differed quantitatively in composition, probably the result of bacterial respiration. Coralla of several scleractinian species can float following desiccation after beaching during storms. Whilst uncommon, drifting coralla may have been of considerable significance as agents of dispersal over geological time, as biogenic carbonates are the usual settlement substrata of most sessile reef species.
\end{abstract}

The dispersal of terrestrial and marine organisms on floating objects has long been of scientific interest, from both biogeographic and ecological viewpoints. For some species, extension of biogeographic ranges is more likely to be related to transport of mature individuals on floating rafts than to the active or passive dispersal of reproductive propagules (Jokiel 1984 , 1990, Jackson 1986). The availability and variety of rafting materials has increased dramatically with the spread of human populations around the world's coastlines. Ships' hulls, glass and plastic bottles, and even items of footwear have been used as rafts by 'hitchhiking' species. All are relatively recent additions to the marine environment.

Prior to the spread of humanity, volcanic pumice, trees and seeds were the most ubiquitous of natural rafts, sometimes drifting for years and covering thousands of kilometres of ocean before landfall. For example, tree trunks and pumice that washed ashore at Cocos (Keeling) Atoll in the early 1900's had been

\footnotetext{
- Present address: Australian Institute of Marine Science, PMB 3, Townsville MC, 4810 Queensland, Australia
}

drifting for some 20 years, since the eruption of Krakatoa $1000 \mathrm{~km}$ to the northeast in 1883 (WoodJones 1912). Drifting with the logs and pumice were stony coral skeletons in the form of large massive rocks which ... float buoyantly in the sea' (Wood-Jones 1912: p. 292). Wood- Jones identified the corals as species of Astraea, 'the zooid of which is ... very large'. Current taxonomy suggests that the corals probably were members of the family Faviidae that develop meandroid calices.

Fig. 1a shows a dead meandroid colony of the mussid Symphyllia agaricia (approximate dimensions: $50 \times 35$ $\times 15 \mathrm{~cm}$; wet weight: $15 \mathrm{~kg}$; density: 0.91) floating on Feather Reef, some $30 \mathrm{~km}$ from the northeast Australian coastline in the central region of the Great Barrier Reef. Buoyancy was due to gas trapped interstitially between the skeletal dissepiments (Fig. 1b). The gas was qualitatively similar to air, but differed quantitatively in composition (Table 1).

Source of the gas is unknown, however it seems likely that air may have entered the corallum following its beaching during a storm. Silicate sands in crevices on the corallum provided circumstantial evidence of it having been washed ashore. Variations in gas composition between samples suggested that the air had been modified to a greater or lesser extent by bacterial respiration (Table 1). As a matter of historical interest, Wood-Jones attributed buoyancy of the corals that drifted ashore at Cocos (Keeling) Atoll to gas produced and stored in the septal chambers. However, it is unlikely that gas becomes sealed into the coral skeleton during growth, as septal chambers of the Scleractinia generally are water-filled during life (but see Bellamy \& Risk 1982). In situ corals, whether dead or alive, usually have densities ranging from about 1.1 to 1.9. For corals to become buoyant, the water within the skeleton must be replaced by air (or another gas). Even then, only low-density corals with large septal chambers, such as Symphyllia spp. (Fig. 1b), are likely to float. Density of the $S$. agaricia corallum was 0.91 . 

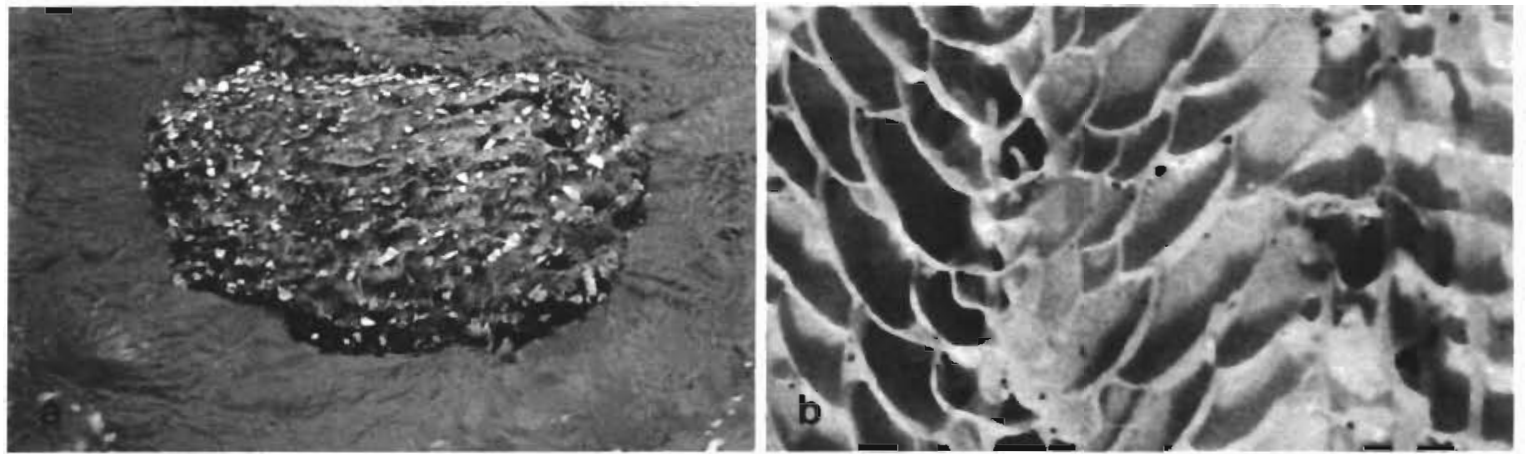

Fig. 1. Symphyllia agaricia. (a) Buoyant skeleton of reef coral floating on Feather Reef, central Great Barrier Reef. The algalcovered corallum supported a variety of benthos, including the ubiquitous goose barnacles Lepas anserifera notable in the photo.

(b) Internal structure of coral: septal chambers and dissepiments $(\times 4$ magnification)

Table 1. Gas chromatograph analysis (percent by volume) of 2 samples of gas from the Symphyllia agaricia corallum

\begin{tabular}{|ccccccc|}
\hline Sample & $\begin{array}{c}\text { Nitrogen } \\
\left(\mathrm{N}_{2}\right)\end{array}$ & $\begin{array}{c}\text { Oxygen } \\
\left(\mathrm{O}_{2}\right)\end{array}$ & $\begin{array}{c}\text { Carbon } \\
\text { dioxide } \\
\left(\mathrm{CO}_{2}\right)\end{array}$ & $\begin{array}{c}\text { Carbon } \\
\text { monoxide } \\
(\mathrm{CO})\end{array}$ & $\begin{array}{c}\text { Hydrogen } \\
\left(\mathrm{H}_{2}\right)\end{array}$ & $\begin{array}{c}\text { Methane } \\
\left(\mathrm{CH}_{4}\right)\end{array}$ \\
\hline 1 & 84.2 & 15.7 & 0.07 & 0.006 & 0.001 & 0.001 \\
2 & 81.1 & 18.8 & 0.09 & 0.0003 & 0.001 & 0.001 \\
Air & 78.1 & 20.9 & $<0.04$ & $<0.0001$ & $<0.0001$ & 0.0002 \\
\hline
\end{tabular}

When found, the corallum was covered in crustose coralline and filamentous blue-green algae and supported a variety of other organisms, including goose barnacles Lepas anserifera $(\mathrm{n}=578)$, crabs Thalamita stimpsoni $(\mathrm{n}=5)$, pearl and reef oysters Pinctada maculata $(\mathrm{n}=2)$, $P$. albina $(\mathrm{n}=7)$, and Crassostrea amasa ( $\mathrm{n}=16)$, gastropods Astraea sp. ( $\mathrm{n}=5)$, Bryozoa $(\mathrm{n}=150+)$ and Foraminifera $(\mathrm{n}=21)$. The size frequency distributions of the barnacle and oyster cohorts (mean valve length for $P$. albina: $13 \pm 2 \mathrm{~mm}$; . amasa: $6 \pm 1 \mathrm{~mm}$ ) suggested that the corallum had been floating for at least several months. This estimate was based on the assumptions that the corallum had become buoyant following its beaching and desiccation, and that the organisms settled following floatation.

Coralla of at least 2 other species of scleractinian coral also float when dry - Oulophyllia crispa and Colpophyllia natans. Both species are members of the Faviidae that develop meandroid calices, the former distributed throughout the Indo-West Pacific, the latter throughout the Caribbean Sea. Buoyant coral skeletons are relatively rare in comparison with other floating objects and probably of little importance as a means of dispersal in today's flotsam-filled oceans. However, over geological time prior to the spread of humanity, their significance as agents of dispersal for tropical marine organisms may have been considerable. Biogenic carbonates are the usual settlement substrata of many sessile coral reef species. As Wood-Jones (1912: p. 292) concluded: 'Floating coral ... might easily increase the coral fauna (on isolated reefs), for it is a regular thing in coral bionomics that a young colony starts its growth upon an older one'.

Acknowledgements. I thank Alan Nott, David Barnes, John Veron, Inara Bush and John Keesing for valuable assistance. This study was undertaken using the facilities of the Australian Institute of Marine Science.

\section{LITERATURE CITED}

Bellamy, N., Risk, M. J. (1982). Coral gas: oxygen production in Millepora on the Great Barrier Reef. Science 215: $1618-1619$

Jackson, J. B. C. (1986). Modes of dispersal of clonal benthic invertebrates: consequences for species' distributions and genetic structure of populations. Bull. mar. Sci. 39: 588-606

Jokiel, P. L. (1984). Long distance dispersal of reef corals by rafting. Coral Reefs 3: 113-116

Jokiel, P. L. (1990). Transport of reef corals into the Great Barrier Reef. Nature 347: 665-667

Wood-Jones, F. (1912). Corals and atolls. Lovell Reeve and Co. Ltd., London

Manuscript first received: May 12, 1992

Revised version accepted: July 20, 1992 